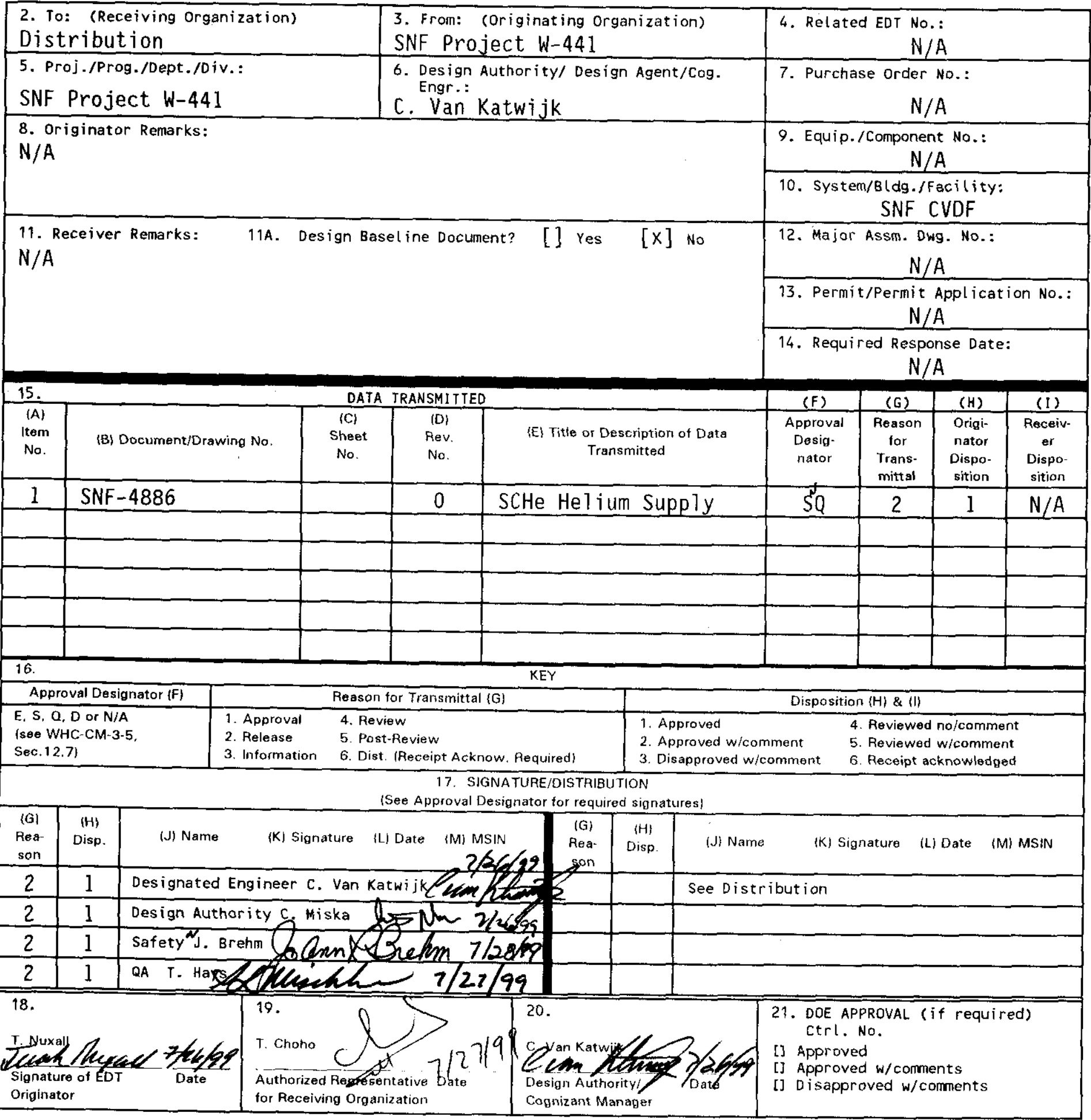

BD-7400-172-2 (05/96) GEF097 


\section{SCHe HELIUM SUPPLY}

Carl Van Katwijk

Numatec Hanford, Richland, WA 99352

U.S. Department of Energy Contract DE-AC06-96RL13200

EDT/ECN: 626323

Org Code: $2 \mathrm{G} 300$

B\&R Code: 39EW40400
UC: 620

Charge Code: $105559 / \mathrm{A} 000$

Total Pages: 4

Key Words: SCHe Helium Supply

Abstract: SCHe Helium Supply

TRADEMARK DISCI.AIMER. Reference herein to any specific commercial product, process, or service by trade mame, trademark. manufacturer, or otherwise, does not necessarily constitute or imply its endorsenent, recommendation, or favoring by the $I_{1 n i t e d ~ S t a t e s}$ Government or any agency thereof or its contractors or subcontractors.

Printed in the United States of America. To obtain copies of this document, contact: Documem Control Services, P.O. Box 950, Mailstop H6-08, Richland WA 99352, Phone (509) 372-2420: Fax (509) 376-4989.

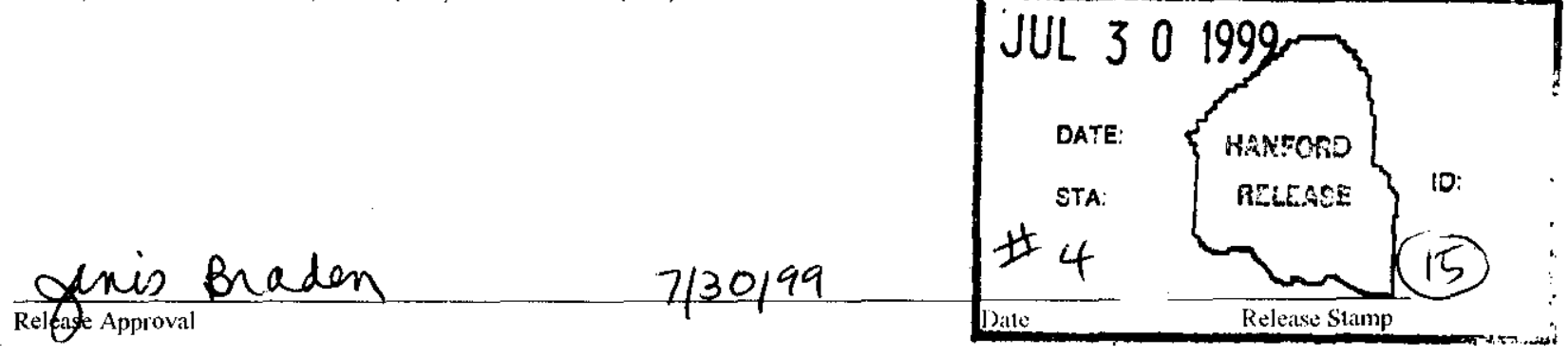

\section{Approved for Public Release}


Commercial Grade Item Upgrade Dedication Form

SNI:-48XG. ReV. 0

ECN No. NA CGINo. CGI-SNF-D-13-2-P5-051

Page 1 of 3

Title: SCHe HELIUM SUPPLY

Section 1 Part Information

Item No.: NA

Manufacturer:

Supplier:

Mfg. PartModel No::

Supplier's P/N:

Part Description:

End Use Description:

\begin{tabular}{|c|c|c|c|}
\hline $\begin{array}{l}\text { Equipment No.: This CGI } \\
\text { addresses the helium } \\
\text { gas to be charged into } \\
\text { the SCHe bottles, } \\
\mathrm{SCHe} \mathrm{TK}-5 * 01,5 * 02 \text {, } \\
5 * 03 \text { and } 5 * 04 \text {. } \\
\text { Equipment number is } \\
\text { not applicable for the } \\
\text { gas. }\end{array}$ & $\begin{array}{l}\text { Specification No.: } \\
\text { W-441-P5, Rev. } 2\end{array}$ & Manufacturer: NA & Past P.O. No.: \\
\hline $\begin{array}{l}\text { Manufacturer's Part } \\
\text { Model No.: NA }\end{array}$ & \multicolumn{2}{|c|}{ Gas Supplier (if different from manufacturer): LATER } & $\begin{array}{l}\text { Equip. Supplier's Part No:: } \\
\text { NA }\end{array}$ \\
\hline
\end{tabular}

Component Description: The SCHe bottles are dedicated for safety use by CGI-SNF-D-13-2-P5-050.

That CGI does not include the gas. The gas is important to the emergency MCO purge. The gas purity and pressure must be controlled items to satisfy the assumptions made in the safety analyses.

\section{Section $2 \mathrm{~b}$ Commercial Avallability of the llem}

1. Is the Item available from a catalogue of a qualified NQA1 supplier? (coordinate with project CGI interface Engineer or BTR)

[X] YES (go to \#2 below)

( ] NO (go to procedure step 6.3.2, proceed to dedicate Item.)

If not available from a qualified NQA1 supplier, is it available from an $1 S 09000$ supplier? (coordinate with project CGI interface Engineer or BTR)

[ ] YES (go to \#2 below, then go to procedure step 6.3.2, proceed to dedicate Item)

[ I NO (go to procedure step 6.3.2, proceed to dedicate item.)

2. List of Candidate qualified suppliers or ISO 9000 suppliers

company name \& type

contact name

phone

\section{LATER}




\begin{tabular}{|c|c|}
\hline Commercial Grade Item Upgrade Dedication Form & SNIF-4886, Rev. 0 \\
\hline $\begin{array}{l}\text { ECN No. NA CGI No. CGI-SNF-D-13-2-P5-051 } \\
\text { Title: } \text { SCHe HELIUM SUPPLY }\end{array}$ & l'age 2 of 3 \\
\hline
\end{tabular}

3. Recommended Procurement Strategy (coordinate with project CGI interface Engineer or BTR):

The $\mathrm{SCHe}$ helium bottles dedicated for CVDF use, will be charged with helium gas by a Qualified Supplier. The Qualified Supplier will be provided with the bottles procured and dedicated for CVDF exclusive use. The bottle documentation will include individual bottle serial numbers. The Qualified Supplier will maintain bottle inventory control and tracking when shipping charged bottles and receiving bottles to be charged. This control will ensure that only the bottles dedicated for CVDF use will be charged and shipped to CVDF and likewise the dedicated bottles will not be used at other Hanford locations.

The critical characteristics for the SCHe helium supply is purity $(99.997 \%)$, pressure (nominal $2490 \mathrm{psig}$ ) and bottle serial number. Documentation provided by the Qualified Supplier with the bottle shipments will include those characteristics; serial number, pressure, and helium purity. This documentation will provide reasonable assurance that the bottle is from the controlled lot and contains the specified contents.

\section{Section 2c CGI Determination}

1. Question\#1: is the Item subject to design or specification requirements that are unique to nuclear facilities or activities?

[ $\mathrm{X}$ ] YES (the Item is not commercial grade) The requirements for bottle inventory control and for critical characteristics with exclusive application to CVDF make this item unique to this nuclear facility.

1 I $N O$ (continue)

2. Question \#2: Is the Item used in applications other than nuclear facilities or activities?

[ ] NO (the item is not commercial grade)

[X] YES (continue)

3. Question \#3: Is the Item ordered from manufacturer/supplier on the basis or specifications set forth in the published product information (e.g., manufacturer's catalog)?

[ ] $\mathrm{NO}$ (the Item is not commercial grade)

[X] YES (continue)

[ ] All three criteria have been satisfied. The Item meets the definition of commercial grade.

[X] It is determined that the item is not commercial grade. The item is currently specified to be procured from a Qualified Supplier and commercial grade dedication is not required.

Section 2d Reason for Dedication

The above described Item is being Dedicated for use in the application cited for the following reason(s):

Section 3 Failure Effects Evaluation

Section 4 Environmental \& Natural Phenomena Hazard Design

Section 5 Component Functional Classification

Section 6 [reserved]

Section 7 [reserved]

Section 8 References (for Functional Classification) 


Commercial Grade Item Upgrade Dedication Form
\begin{tabular}{|l|l|}
\hline ECN No. NA & SNR-4886. Rov. i) \\
Title: SCHe HELIUM SUPPLY & Patge 3 of 3 \\
\hline
\end{tabular}

Section 9 Critical Characteristics

Notes and Legend: The helium gas is procured from a Qualified Supplier

Acceptance Method: and does not require CGI procurement dedication.

1. Special Test and Inspection

1, IN for Inspection

1,T forTest

2. Commercial Grade Survey

3. Source Verification

4. Vendor/item History

Section 10 Initial Review and Approval

Approvals:

Designated Engineeg ECane

Design Authority: Na DN 2/26/99

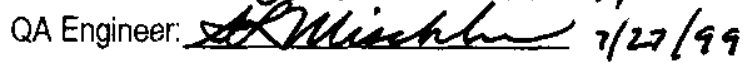




\section{DISTRIBUTION SHEET}

To

Distribution

Project TitleNWork Order

W-441, SNF-4886, SCHe Helium Supply
From

SNE-CVD
Page 1 of 1

Date $7 / 22 / 99$

EDT No. 626323

ECN No. N/A

\begin{tabular}{|c|c|c|c|c|} 
MSIN & $\begin{array}{c}\text { Text } \\
\text { With All } \\
\text { Attach. }\end{array}$ & Text Only & $\begin{array}{c}\text { Attach. } \\
\text { Appendix } \\
\text { Only }\end{array}$ & $\begin{array}{c}\text { EDT/ECN } \\
\text { Only }\end{array}$ \\
\hline
\end{tabular}

C. Miska

C. Van Katwijk

K. Boes (CVD Library)

m.Haystem 7/27/94 R. Ramsgate

J. Brehm

D. Whitworth

P. Morrell (AVS)

M. Evarts (AI)

D. Marburger

\section{Mischke}

SnF Statop

\section{Name}

$\mid$

R3-86

R3 -47

$\mathrm{R} 3-86$

R3-86

R3-26

R3-11

G1-50

$\mathrm{N} 1-29$

R3-47

R3-86

B2-64 $x$

$\mathrm{x}$

$x$

$x$

$x$

$x$

$x$

$x$

$x$

$x$

